\title{
Adding value to polystyrene waste by chemically transforming it into sulfonated polystyrene
}

Bruna Torres Negreiros Cordeiro Andrade ${ }^{1}$, Augusto Cesar da Silva Bezerra ${ }^{1}$, Claudinei Rezende Calado ${ }^{1}$

\footnotetext{
${ }^{1}$ Centro Federal de Educação Tecnológica de Minas Gerais - CEFET-MG - Departamento de Engenharia de Materiais, Belo Horizonte, Minas Gerais, Brasil.

e-mail: bruna.andrade@gmail.com, augustobezerra@des.cefetmg.br, crcalado@des.cefetmg.br
}

\begin{abstract}
Polystyrene (PS), one of the most used polymers in everyday life, has a low recycling rate due to its inexpensive virgin resin. In order to make polystyrene waste (WPS) recycling advantageous, it is possible to change it chemically, introducing heteroatoms in the polymer chain thus transforming the waste into a material with more added value. In this work, sulfonation reactions of polystyrene waste (disposable cups and expanded polystyrene - EPS) with different degrees of sulfonation were carried out by homogeneous sulfonation using acetylsulfate as a sulfonating agent, originating polystyrene sulfonate (PSS). The characterization of the products was done using Fourier Transformed Infrared Spectroscopy (FTIR), solubility tests and inductively coupled plasma optical emission spectroscopy (ICP-OES). Infrared spectroscopy revealed that the reaction was efficient and all the starting materials tested were successfully sulfonated and transformed into PSS. There was no distinction between the residues tested, revealing that it's possible to carry the reaction without sorting the waste. EPS was chosen as the substrate for further reactions varying the degree of sulfonation. Solubility and ICP-OES tests have shown that, by changing the synthesis conditions, it is possible to achieve different degrees of products sulfonation. As a result of the studied reactions it was found that varying the degree of sufonation it is possible to use polystyrene residues to produce PSS for different applications.
\end{abstract}

Keywords: Polystyrene, Waste, Sulfonated polystyrene, Sulfonation, Recycling, Expanded polystyrene.

\section{INTRODUCTION}

Polystyrene (PS) is a high molecular weight linear thermoplastic resin widely used in everyday life in a variety of applications ranging from packaging materials to electronic cabinets and household appliances, automotive and other industries. In the packaging sector products such as disposable cutlery, vending cups, coffee pods, egg and meat trays, salad boxes, soup bowls and hamburger clam shell are mostly made from PS. In the electronic and electrical sector, polystyrene comes mostly in forms of media closures $[1,2,3]$.

PS is most often commercialized as a clear, odorless, hard, colorless, tasteless material that displays outstanding properties such as good mechanical strength, thermal stability, relatively low density besides its low production cost. Its structure of phenyl groups and single C-C bonds (Figure 1) makes polystyrene highly stable and resistant to decomposition. It also presents good UV stability and resistance to gamma radiation which means PS is frequently used in products that require sterilization. The polymer is manufactured in three main commercial forms: general purpose polystyrene (GPPS) expanded polystyrene (EPS), high-impact polystyrene (HIPS) and a relatively minor grade syndiotatic polystyrene (SPS) [1,2].

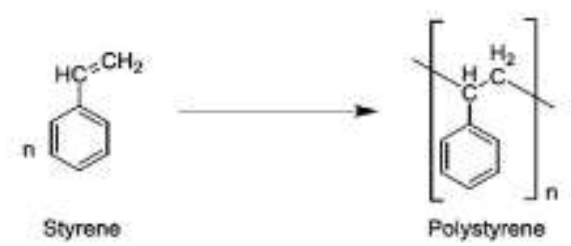

Figure 1: Chemical structure of Polystyrene. The polymer is a repetition of units of styrene. 
Plastic packaging is one of the most rapidly evolving and technologically sophisticated end used for plastics. However, at the end of its useful life, plastic packaging are still seen as a problem and their disposal has become an worldwide issue. The vast majority of PS packaging is disposed of in landfills, waste dumps and sometimes even thrown into the ocean as disposal method. Around $75 \%$ of all the litter in our oceans is plastic, and an estimated 5 million tons of plastic waste enter the seas annually. An alternative to landfills, waste dumps and ocean littering is incineration, which produces gases such as COx, NOx, SOx and polyaromatic hydrocarbons (PAHs) that are toxic and carcinogenic. For the year of 2016 United States consumed 1609 thousand metric tons of PS and less than $1 \%$ of it was recycled. For the last 15 years the recycling rate of polystyrene has never been above $1.2 \%$ and the estimates for the next 5 years is that it remains constant at $0.9 \%[1,3,4,5]$.

According to ORMONDE et al.[3], nowadays, the main obstacle to plastic recycling/reclamation is the continued low price of oil, the raw material from which plastics are made. The authors suggest that in order to be successful the recycling industry must innovate, integrate to add value and create new products and market.

As an effort to add value to polystyrene waste (WPS), an alternative for its recycling is to change it chemically transforming the waste into a material with more added value. The introduction of heteroatoms in the polymeric chain changes its physical, chemical and mechanical properties and, consequently, its conductivity, hydrofilicity, solubility, acidity and other properties. These properties can be customized to specific purposes6. Therefore, the waste material is converted into a higher value substance.

Sulfonation of polystyrene, in other words, the insertion of acid sulfonic groups $\left(-\mathrm{SO}_{3} \mathrm{H}\right)$ in the polymer chain, produces polystyrene sulfonate (PSS), a polyelectrolyte that can be used in a wide range of applications. Unique properties arise from this modification of the polymer chain and, by varying the degree of sulfonation in PSS, it is possible to tune the polymer's properties, making it suitable for the desired application. This structure modification on the structure and the possibility of controlling the polymer's new properties have led to an exploration of a variety of applications, such as biocompatible electrodes [7], stimuli-responsive photonic crystals [8], humidity sensors [9,10], components of photovoltaic devices $[11,12,13]$ ion exchange membranes $[14,15,16,17]$, flocculant material for water treatment $[18,19]$ and catalysts $[20,21]$.

PSS structure is shown in Figure 2, where the units of $\mathrm{x}$ and $\mathrm{y}$ change depending on the sulfonation degree of the polymer. The greater the value of $x$ and thus, the smaller the value of $y$, the higher is the degree of sulfonation of the polymer.

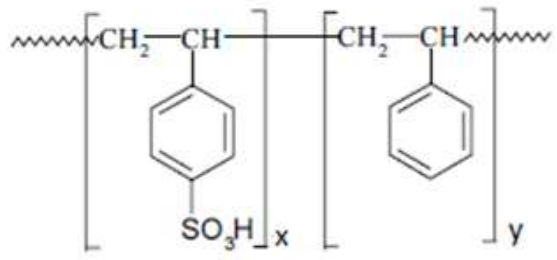

Figure 2: Chemical structure of PSS.

Polymer sulfonation can be a heterogeneous reaction when the polymer and the sulfonating agent are in different phases or a homogeneous reaction using hydrocarbons or chlorinated solvents so that all the reactants are in liquid state [22]. When the sulfonation of a polymer occurs after its polymerization (as is the case of sulfonating a residue) and the reaction is conducted in homogeneous medium, the solubility of the polymers (which is generally good in strong acids and chlorinated organic solvents) and the solvent compatibility with other reactants are key factors for the success of the reaction. An alternative to sulfonation conducted without these solvents is a heterogeneous sulfonation. In this case, the polymer in its natural state (solid) is immersed in a solution containing the sulfonating agent. As sulfonation takes place, $-\mathrm{SO}_{3} \mathrm{H}$ groups inserted in the chain modify the material solubilization, and it becomes soluble in the sulfonating agent solution [23].

According to RODRIGUES FILHO et al. [18], the sulfonation reaction most commonly used to produce PSS is the homogeneous route. PS is solubilized in dichloroethane in the presence of acetylsulfate, produced by the reaction of acetic anhydride with concentrated sulfuric acid, as a sulfonating agent. MAKOWSKY et al. (1975, apud RODRIGUES FILHO et al. [18]) states that, using this route, the reaction occurs without significant degradation of PS and formation of crosslinks due to acetylsulfate being a mild sulfonating agent. This reaction leads to random insertions of the sulfonic acid group in the polymer chain. 
The route of synthesis proposed by Makowsky is the basis used by several authors to produce the PSS. Other authors also use this route to sulfonate other types of polymers, such as polycarbonate (PC) [24,25], poly (styrene-isobutylene styrene) [6], Polyetherketones (PEK), polysulfide (PPS), polysulfones (PSU) and others.

In this paper chemical transformation of polystyrene waste into polystyrene sulfonate is performed using the homogeneous rout (with dichloromethane acting as solvent and the reaction product of sulfuric acid and acetic anhydride - acetylsulfate - as the sulfonating agent) with different degrees of sulfonation achieved by different reaction parameters (type of WPS, reaction time, and amount of acetylsulfate used). The degree of sulfonation determines the properties (such as thermal stability and solubility) of the material, thus impacting on its possible uses. Three different types of WPS were tested in order to verify the differences between them and if there was a residue more suitable to the reaction. Fourier Transformed Infrared Spectroscopy (FTIR), Inductively Coupled Plasma - Optical Emission Spectroscopy (ICP-OES) and solubility in different solvents were used to characterize the products.

\section{MATERIALS AND METHODS}

\subsection{Materials}

Three kinds of polystyrene residues were used: (a) white disposable cup, (b) transparent disposable cup and (c) EPS disposable cup (Figure 3). Although (a) and (b) are made of general purpose polystyrene, the difference in color of these cups are an indicative that different additives were used in each of them. Sulfuric acid $\left(\mathrm{H}_{2} \mathrm{SO}_{4} 97 \%\right.$ Sigma Aldrich \#258105) and acetic anydride $\left(\left(\mathrm{CH}_{3} \mathrm{CO}\right)_{2} \mathrm{O}\right.$ Sigma Aldrich \#242845) were used to produce acetylsulfate, the sulfonation agent of the reaction. Dicloromethane $\left(\mathrm{CH}_{2} \mathrm{Cl}_{2}\right.$ Sigma Aldrich \#270997), Isopropylic alcohol $\left(\mathrm{CH}_{3} \mathrm{CHOHCH}_{3}\right.$ Sigma Aldrich \#278475) and distilled water were used as solvents.

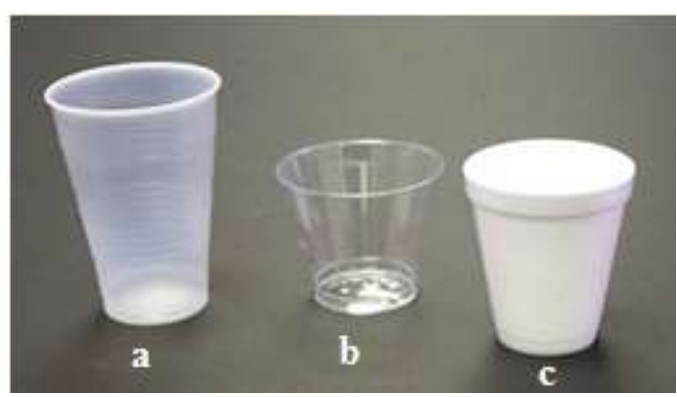

Figure 3: Waste Polystyrene used on the reactions. (a) white disposable cup, (b) transparent disposable cup and (c) EPS disposable cup.

\subsection{Methods}

The method used for homogeneous sulfonation is in agreement with that described by MARTINS et al.[26] and is briefly described as follows: acetylsulfate solution was prepared in a beaker, with the amounts of dichloromethane, acetic anhydride and sulfuric acid shown in Table 1. First, the solution of dichloromethane and acetic anhydride was cooled in an ice bath to the temperature of $4{ }^{\circ} \mathrm{C}$. Then, sulfuric acid was carefully added. This solution was kept under magnetic stirring during 10 minutes and kept in ice bath until its addition to the reaction medium. Excess of acetic anhydride was used to ensure that all added sulfuric acid was converted to acetylsulfate. The sulfonating agent was prepared immediately prior to use in the sulfonation reaction.

For the sulfonation reaction polystyrene was dissolved in dichloromethane in a three-necked flask $(250 \mathrm{~mL})$ and under magnetic stirring. A vigreux column was attached to the flask and after complete dissolution of polystyrene, acetylsulfate solution was slowly dripped. The system was then heated by a thermostatic bath at the reflux temperature of the solvent (approximately $40{ }^{\circ} \mathrm{C}$ ). After the time stipulated in Table 1, the reaction was quenched by addition of isopropylic alcohol followed by a further 30 minutes of stirring.

All syntheses were carried out using $4 \mathrm{~g}$ of polystyrene waste. The proportions between sulfuric acid and anhydride acetic were kept the same for different amounts of acetylsulfate produced. At first, each type of WPS was sulfonated maintaining all the other parameters constant. Later, EPS was chosen as a substrate for further tests. In those tests, the influence of two variables in the degree of sulfonation was evaluated: 
amount of sulfonating agent, sulfuric acid (1,2 and $3 \mathrm{~mL})$ and reaction time (3, 6 and 9 hours). The solvents employed in the reaction were reclaimed by using a rotary evaporator and controlling the temperatures with a steam bath, thus making the process of waste transformation even more sustainable.

Table 1: Type of polystyrene waste, quantities and parameters used in the reactions.

\begin{tabular}{c|c|c|c|c|c}
\hline SAMPLE & PS WASTE & PS $\mathbf{( g )}$ & $\begin{array}{c}\text { ACETIC ANYDRIDE } \\
\mathbf{( m \mathbf { m } )}\end{array}$ & $\begin{array}{c}\text { SULFURIC ACID } \\
(\mathbf{m L})\end{array}$ & $\begin{array}{c}\text { REACTION TIME } \\
(\mathbf{h})\end{array}$ \\
\hline PSS-TDC & Transparent disposable cup & 4 & 3 & 1 & 3 \\
\hline PSS-WDC & White disposable cup & 4 & 3 & 1 & 3 \\
\hline PSS-EPS & EPS & 4 & 3 & 1 & 3 \\
\hline PSS-EPS-01 & EPS & 4 & 3 & 1 & 3 \\
\hline PSS-EPS-02 & EPS & 4 & 6 & 2 & 6 \\
\hline PSS-EPS-03 & EPS & 4 & 9 & 3 & 9 \\
\hline
\end{tabular}

The products and starting materials were characterized with solubility test, Fourier Transformed Infrared Spectroscopy (FTIR) and Inductively Coupled Plasma - Optical Emission Spectroscopy (ICP-OES) techniques. The solubility test was carried out with $0.1 \mathrm{~g}$ of the starting materials and sulfonated products in $10 \mathrm{~mL}$ of solvent. Three solvents were used: dichloromethane, isopropyl alcohol and distilled water. After the polymer was added to the solvent, the system was submitted to magnetic stirring for 10 minutes. The tests results were qualitative, being simple soluble or non-soluble. It was observed whether there was any solid material left in the solution after the stirring time or weather the polymer was completely soluble in giver solvent. Fourier Transformed Infrared Spectroscopy: infrared spectra were obtained in a SHIMADZU Spectrometer, model Prestige-21 with the aid of an ATR accessory following experimental conditions: measuring range of 4000 to $400 \mathrm{~cm}-1$, number of scans of 64 and resolution of 2.0. The Inductively Coupled Plasma - Optical Emission Spectroscopy (ICP-OES) analysis was carried out in the equipment Optical Atomic Emission Spectrometer with Inductively Coupled Plasma (ICP OES, Radial) Spectro, model Arcos. Samples were digested using Schöninger digestion methodology.

\section{RESULTS AND DISCUSSION}

Sulfonated polymer solubility was used as a qualitative parameter for assessing whether the reaction products had different degrees of sulfonation. Polystyrene is a non polar polymer and as sulfonate groups are inserted into its chain, the polarity of the molecule increases, therefore increasing chain polarity and consequently polymer solubility in more polar solvents. Table 2 shows the results for the solubility test performed. It's marked as "yes" if given sample was soluble in the solvent and "no" if it's weather inert to it.

Table 2: Solubility of WPS and samples tested.

\begin{tabular}{c|c|c|c}
\hline SAMPLE & DICHLOROMETHANE & $\begin{array}{c}\text { ISOPROPYLIC } \\
\text { ALCOHOL }\end{array}$ & WATER \\
\hline Transparent disposable cup & Yes & No & No \\
\hline White disposable cup & Yes & No & No \\
\hline EPS & Yes & No & No \\
\hline PSS-TDC & Yes & No & No \\
\hline PSS-WDC & Yes & No & No \\
\hline PSS-EPS & Yes & No & No \\
\hline PSS-EPS-01 & Yes & No & No \\
\hline PSS-EPS-02 & No & Yes & Yes \\
\hline PSS-EPS-03 & No & & \\
\hline
\end{tabular}

The tests demonstrate that WPS, PSS-TC, PSS-WC, PSS-EPS and PSS-EPS-01 were soluble in dichloromethane and insoluble in isopropylic alcohol and water, which indicates that the chains of these samples are apolar, as dichloromethane is an apolar solvent. These sulfonated products have incorporated few 
sulfonate groups (hypothesis confirmed by other characterization methods described later) but are still predominantly apolar.

Also, the results showed that PSS-EPS-02 was soluble in isopropylic alcohol and insoluble in water and dichloromethane. This indicates that there are more groups sulfonate in the chain of PSS-EPS-02 than on PSS-EPS-01. The polarity of the macromolecule is still not high enough for it to be soluble in water (the most polar solvent tested), but enough for it to be soluble in a moderate polar solvent such as this alcohol.

Finally, PSS-EPS-03 was soluble in water and not soluble in the other two solvents. This result supports the idea that this sample has the higher degree of sulfonation amongst all the reaction products. The quantity of sulfonate groups inserted in the polymer chain changed significantly the polarity of the molecule.

FTIR spectra of the residues used as starting materials in the reactions are shown in Figure 4. It is possible to identify the main bands of the polymer structure in their infrared spectra. Typical band of stretch vibration of the $\mathrm{C}-\mathrm{H}$ bond of aromatic rings can be identified at $3025 \mathrm{~cm}^{-1}$ (a), the band characteristic of the symmetrical stretch of $\mathrm{CH}_{2}$ is also observed in $2840 \mathrm{~cm}^{-1}$ (b), as well as the antisymmetric deformation of these groups In $1450 \mathrm{~cm}^{-1}$ (d). The vibration of the aromatic skeleton is represented in the band at $1600 \mathrm{~cm}^{-1}$ (e). The bands between $906 \mathrm{~cm}^{-1}$ and $750 \mathrm{~cm}^{-1}$ are associated with vibration of $\mathrm{C}-\mathrm{H}$ deformation of the aromatic ring $[23,27,28]$. Also (c), in EPS spectrum, it is possible to observe the presence of a thin band in the region of $1770 \mathrm{~cm}^{-1}$ relative to the $\mathrm{CO}_{2}$ trapped in the structure, since this gas is trapped in the grid formed in the expanded polystyrene.

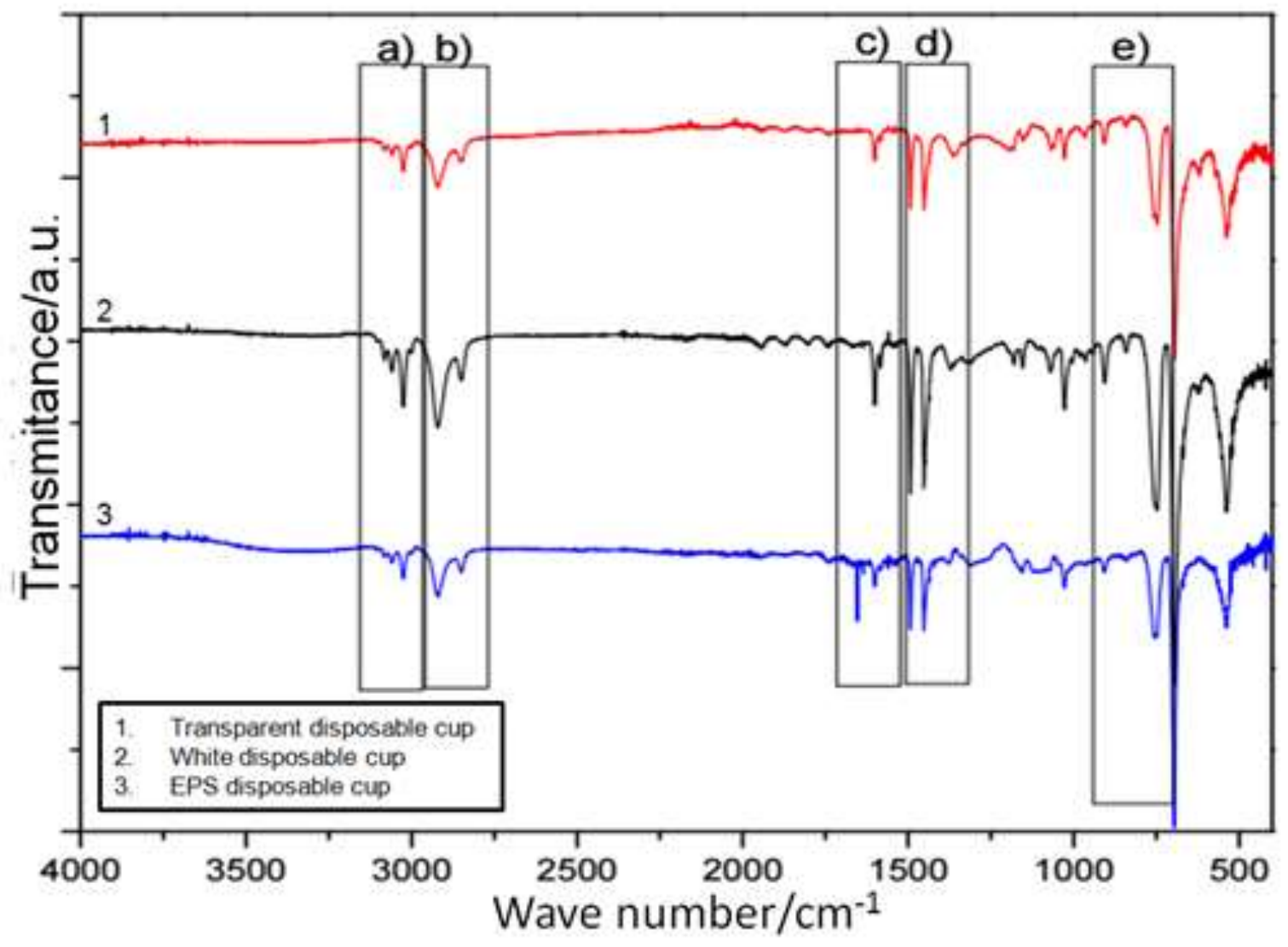

Figure 4: FTIR spectra of the residues used as starting materials on the reactions.

All three types of WPS tested were successfully sulfonated using the method described. FTIR analysis of PSS (Figure 5) showed the presence of the bands relative to S-O that were not present in the waste spectra. The occurrence of $-\mathrm{SO}_{3}$ band of symmetric stretching vibration at $1040 \mathrm{~cm}^{-1}$ and $-\mathrm{SO}_{3}{ }^{-}$antisymmetric stretching vibration at $1180 \mathrm{~cm}^{-1}$ indicates qualitatively the presence of the attached $-\mathrm{SO}_{3} \mathrm{H}$ groups in each of sulfonated samples. The band related to the substituted benzene in the para position $\left(840 \mathrm{~cm}^{-1}\right)$ validates the aromatic ring substitution $[23,27,28]$. 


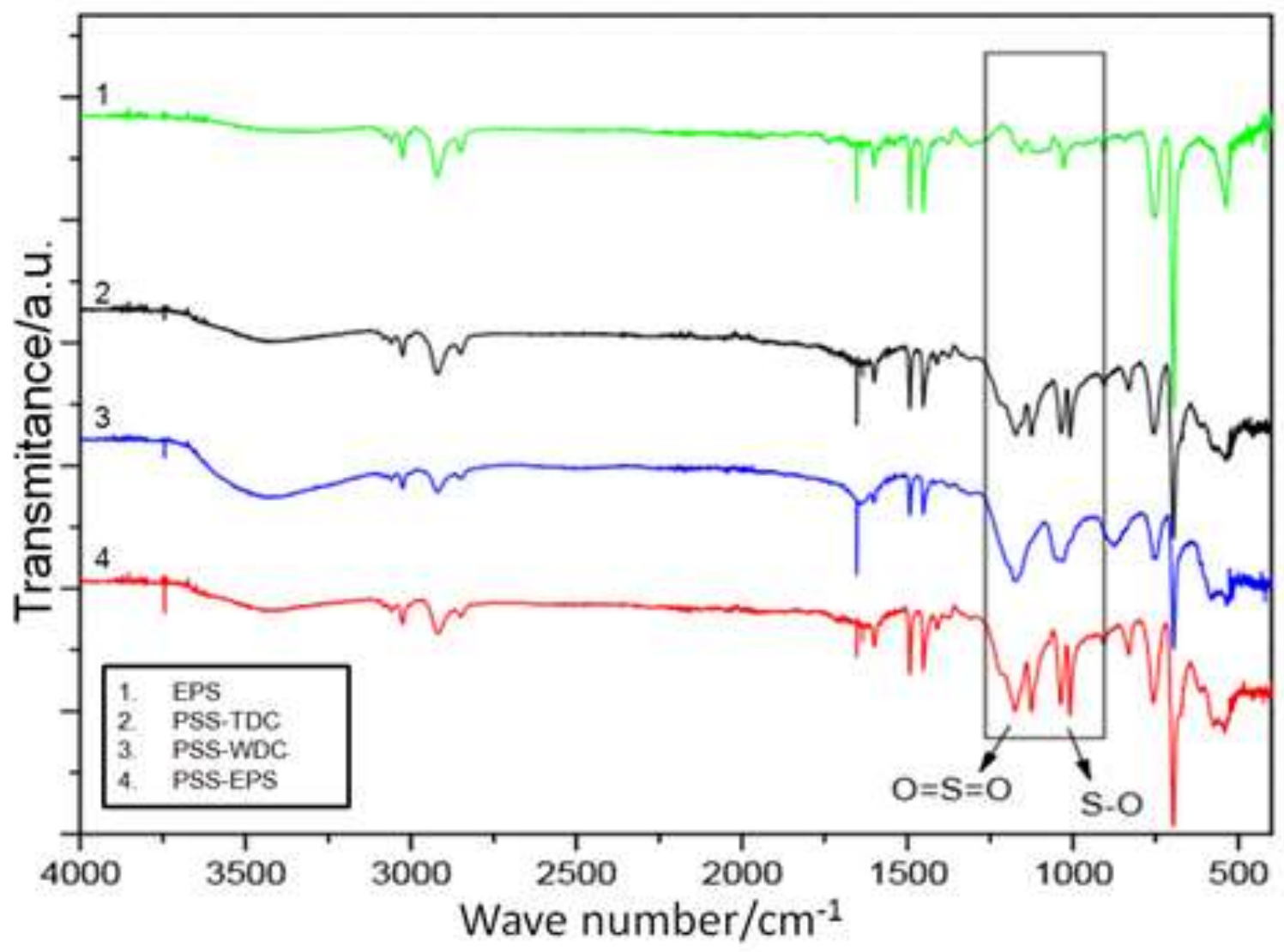

Figure 5: Infrared spectra of EPS, PSS-TDC, PSS-WDC and PSS-EPS.

Once proved that all three types of waste were successfully transformed into polystyrene sulfonate, expanded polystyrene residue was chosen for further tests due to its higher visual impact and bigger volume (for the same mass) on the trash. The expanded polystyrene was sulfonated to different degrees and the products were analyzed. Figure 6 represents the samples' spectra PSS-EPS-01, PSS-EPS-02 and PSS-EPS-03, all produced from expanded polystyrene waste with different reaction parameters.

By observing the samples' spectra one can note the presence of the bands relative to $\mathrm{S}-\mathrm{O}$. $\left(-\mathrm{SO}_{3}{ }^{-}\right.$ symmetric stretching vibration, $-\mathrm{SO}_{3}{ }^{-}$antisymmetric stretching vibration) and also the band related to the substituted benzene in the para position. These bands lead us to conclude that the three samples were successfully sulfonated.

Infrared spectroscopy technique is efficient in identifying the functional groups and new formed bonds and was used in this paper in a qualitative way. Therefore, it did not provide information regarding the degree of sulfonation of the products obtained in the reactions. However, it was possible to notice that the bands referring to the sulfonate group were more intense as the solubility of the sample increased in polar solvents, that is, the group- $\mathrm{SO}_{3}$ content increased in the samples.

Infrared spectroscopy and solubility tests were performed in samples made from different waste maintaining other reaction parameters constant. All three residues led to the same product (Figure 6) and with similar degree of sulfonation as solubility results demonstrated. The fact that, prior to sulfonating the residue, polystyrene was solubilized in a solvent may be the reason for the similarity of the products. Once the waste and acetylsulfate were in the same state, reaction occurred in the same way for EPS and PS, as their composition is the same and gases trapped in EPS structure is not a part of the equation once waste is solubilized. 


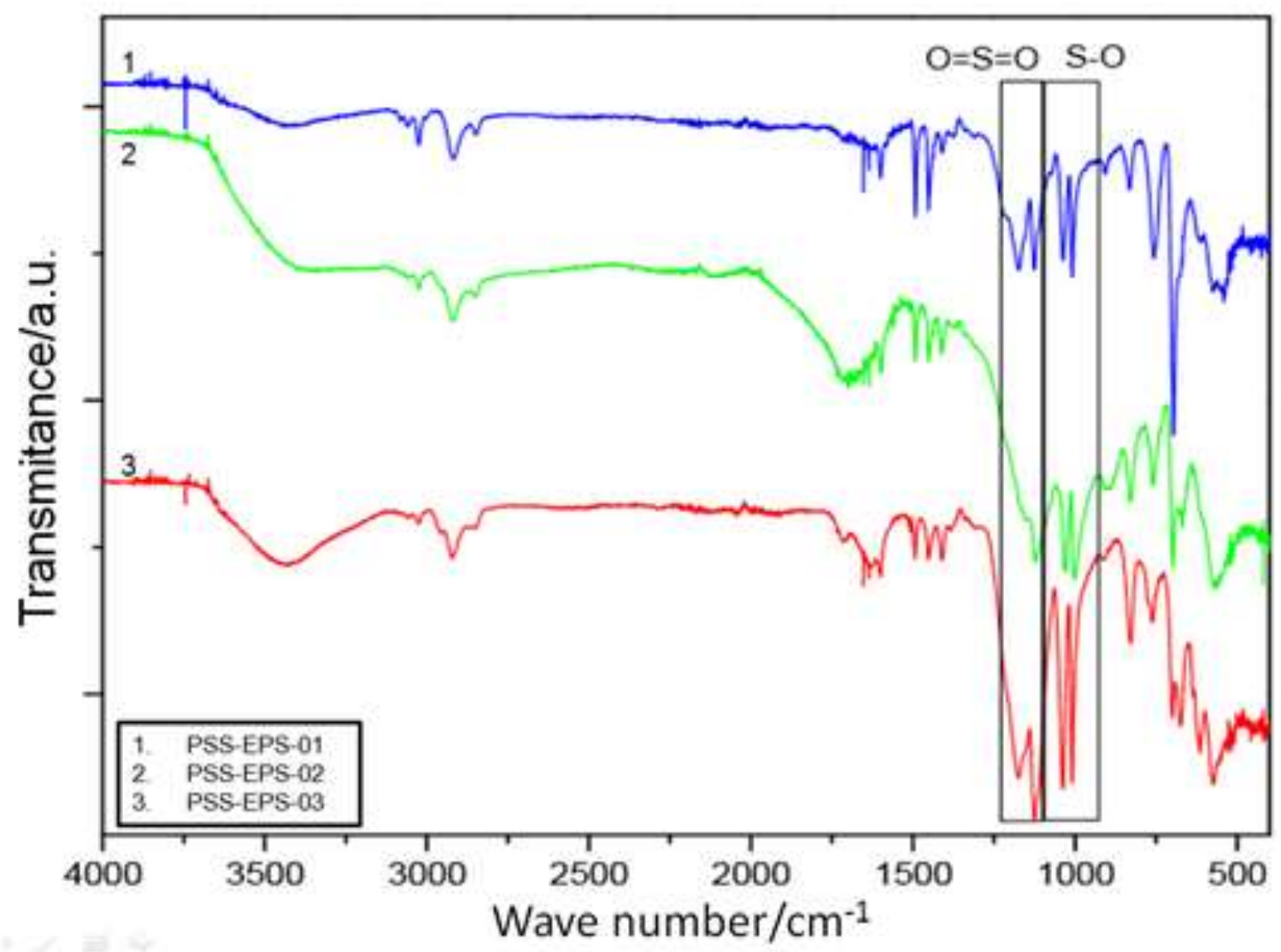

Figure 6: Infrared spectra of PSS-EPS-01, PSS-EPS-02 and PSS-EPS-03.

The Inductively Coupled Plasma - Optical Emission Spectroscopy (ICP-OES) method was used to determine the sulfur content of the samples. From the sulfur percentage result (\% S) it was possible to determine the sulfonation degrees of the polymer, based on the premise that all the sulfur present in the polymer is in the sulfonic acid groups.

The degree of sulfonation is defined as how many moles of $\mathrm{SO}_{3} \mathrm{H}$ groups exist per mole of polymer monomers. In other words, it is the percentage amount of styrene monomer units that have been attached to the sulfonic acid group. In the structure shown in Figure 2, the degree of sulfonation would be how many units of $x$ there are in the whole polymer $(x+y)$. From the results of Sulfur content in ICP-OES, the molar masses of sulfur, sulfonate group and polystyrene repeating unit, it was possible to calculate the samples' degree of sulfonation $\left(\%-\mathrm{SO}_{3} \mathrm{H}\right)$.

Theoretical degree of sulfonation would be the sulfonation degree considering every mole of sulfonate could be inserted inserted to the chain, in a $100 \%$ yeld reaction. The values of theoretical degree of sulfonation for the samples are represented in Table 3, as well as experimental results for percentage of sulfur and the calculated sulfonation degree in the samples for PSS-EPS-01, PSS-EPS-02 and PSS-EPS-03 are shown in Table 3.

These results for degree of sulfonation are consistent with the solubility tests. The sample with the highest degree (PSS-EPS-03) was the only sample soluble in water, the more polar solvent. The sample with the intermediate content of sulfonic groups in the chain (PSS-EPS-02) was soluble on isopropilic alcohol, the solvent with intermediate polarity in the solvents tested. PSS-EPS-01 presented less than 1.5 units of sulfonic groups for each 10 monomeric units in the polymer, quantity that is not enough to change chain polarity in order for it to become soluble in a more polar solvent than dichloromethane such as the alcohol. 
Table 3: Degrees of sulfonation for samples PSS-EPS-01, PSS-EPS-02 and PSS-EPS-03, amount of sulfuric acid used to produce them and theoretical degree of sulfonation.

\begin{tabular}{c|c|c|c|c}
\hline SAMPLE & $\mathbf{H}_{\mathbf{2}} \mathbf{S O}_{\mathbf{4}}$ ADDED $(\mathbf{m L})$ & $\%^{*}$ & $\begin{array}{c}\text { DEGREE OF } \\
\text { SULFONATION } \\
\mathbf{( \% )}\end{array}$ & $\begin{array}{c}\text { THEORETICAL DEGREE } \\
\text { OF SULFONATION (\%) }\end{array}$ \\
\hline PSS-EPS-01 & 1 & 4,01 & 14,7 & 40 \\
\hline PSS-EPS-02 & 2 & 5,80 & 22,2 & 80 \\
\hline PSS-EPS-03 & 3 & 8,70 & 36,7 & 100 \\
\hline
\end{tabular}

$* 1 \%=10.000$ ppm (mg.kg-1 or mg.L $\left.{ }^{-1}\right)$

Although there was a correlation between amount of sulfonating agent used on the reaction and product sulfonation degree it is not a linear function. MARTINS et al.[26] varied the amount of acetylsulfate in order to achieve PSS with higher degrees of sulfonation using atatic PS with relatively low molecular weight (MW) and a narrow MW distribution as starting material. The highest degree of sulfonation obtained was $40 \%$. One hypothesis for a limit of sulfonation degree around $40 \%$ would be steric hindrance between the voluminous sulfonic/sulfonate groups. As the reaction occurs, sulfonic groups are inserted to PS. Once the proportion of approximately $4-\mathrm{SO}_{3}$ for each 10 aromatic rings is reached, steric effects prevents acetylsulfate from aproaching the chain and inserting more groups to the polymer.

Besides increasing the amount of sulfonating agent to the reaction, longer times of reaction were tested simultaneously, in order to test if higher times, in presence of excess of acetylsulfate could lead to higher change to the polymeric chain. Even increasing the time 4.5 fold comparing to the time described by MARTINS et al.[26] it was not possible, for homogeneous sulfonation, to surpass de $40 \%$ limit fo sulfonation degree.

\section{CONCLUSIONS}

In this paper we have accomplished successful sulfonation of all three residues tested: (white disposable cup, transparent disposable cup and expanded polystyrene disposable cup). There was no distinction between the residues tested, which means there is no need to separate the waste prior to the reaction. Further reactions were carried on using expanded polystyrene and different degrees of sulfonation were obtained. The amount of sulfonating agent and reaction time were the parameters that influenced the final amount of sulfonate groups that were successfully linked to the chain of polystyrene. By varying the degree of sulfonation we have shown that it is possible to change the polymer's properties, thus giving the residue a variety of new applications. Those results indicate a new end use for polystyrene waste as an alternative of going to landfills, being thrown into the sea or being incinerated, practices that are, nowadays, very common and very demaging to the environment.

\section{ACKNOWLEGEMENTS}

The authors are grateful to CAPES and FAPEMIG for the financial support and fellowship granted.

\section{BIBLIOGRAPHY}

[1] CHAUKURA, N., GWENZI, W., BUNHU, T., et al., "Potential uses and value-added products derived from waste polystyrene in developing countries: A review", Resources, Conservation and Recycling. v. 107, pp. 157-165, Feb. 2016.

[2] McDERMOT, M. Polystyrene. Nexant. 2016.

[3] ORMONDE, E., YONEYAMA, M., XU, X. Plastics Recycling, Chemical Economics Handbook, IHS Chemical, 2016.

[4] GUTIERREZ, C., RODRIGUEZ, J.F., GRACIA, I. et al., "Reduction of the carbon footprint through polystyrene recycling: Economical evaluation", Process Safety and Environmental Protection, v. 101, pp.144-151, May 2016.

[5] THOMPSON, R., “Environment: A journey on plastic seas”, Nature, v. 547, pp.278-279, Jul. 2017. 
[6] ELABD, Y.A., NAPADENSKY, E., "Sulfonation and characterization of poly (styrene-isobutylenestyrene) triblock copolymers at high ion-exchange capacities", Polymer, v. 45, pp. 3037-3043, Apr. 2004.

[7] PATTANANUWAT, P., TAGAYA, M., KOBAYASHI, T., "Controllable nanoporous fibrillike morphology by layer-by-layer self assembled films of bioelectronics poly(pyrrole-co-formyl pyrrole)/polystyrenesulfonate for biocompatible electrode", Materials Research Bulletin, pp. 260-267, Mar. 2018.

[8] NUCARA, L., PIAZZA, V., GRECO, F. et al., "Ionic Strength Responsive Sulfonated Polystyrene Opals" ACS Applied Materials and Interfaces, v. 9, pp. 4818-4827, Jan. 2017.

[9] LI, Y., ZHAO, H., JIAO, M. et al., "Sulphonated polystyrene-b-poly(4-vinylpyridine) with nanostructures induced by phase separation as promising humidity sensitive material", Sensors and Actuators B: Chemical, v. 257, pp. 1118-1127, Mar. 2018.

[10] RUBINGER, C.P.L., MARTINS, C.R., PAOLI, M.A. et al., "Sulfonated polystyrene polymer humidity sensor: Synthesis and characterization", Sensors and Actuators B: Chemical, v. 123:, pp.42-49, Apr. 2007.

[11] YI, M., HONG, S., KIM, J.R. et al. "Modification of a PEDOT:PSS hole transport layer for printed polymer solar cells", Solar Energy Materials and Solar Cells, v. 153, pp.117-123, Aug. 2016.

[12] LIMA, L.F., MATOS, C.F., GONÇALVES, L.C. et al., "Water based, solution-processable, transparent and flexible graphene oxide composite as electrodes in organic solar cell application", Journal of Physics D: Applied Physics, v. 49, pp. 105-106, Feb. 2016.

[13] JØRGENSEN, M., NORMAN, K., KREBS, F.C., "Stability/degradation of polymer solar cells", Solar Energy Materials and Solar Cells, v. 92, pp.686-714, Jul. 2008.

[14] CARRETA, N., TRICOLI, V., PICCHIONI, F., "Ionomeric membranes based on partially sulfonated poly(styrene): synthesis, proton conduction and methanol permeation", Journal of Membrane Science, v. 166, pp. 189-197, Mar. 2000.

[15] BECKER, C.M. Obtenção e caracterização de polieletrólitos sulfonados à base de copolímeros estirênicos para membranas poliméricas, Dissertation, M.Sc., School of Engineering of Federal University of Rio Grande do Sul, Porto Alegre, Brazil, 2007.

[16] PROENÇA, M.P. Desenvolvimento de membranas ín-seletivas com poliestireno sulfonado $e$ polianilina dopada para a aplicação em eletrodiálise, Dissertation, M.Sc., School of Engineering of Federal University of Rio Grande do Sul, Porto Alegre, Brazil, 2009.

[17] MULLER, F. Membranas poliméricas ín-seletivas aniônicas e catiônicas para uso em eletrodiálise, Thesis, PhD, School of Engineering of Federal University of Rio Grande do Sul, Porto Alegre, Brazil, 2013.

[18] RODRIGUES FILHO, G., ASSUNÇÃO, R.M.N., MARQUES, F.C.A. et al., "Síntese de poliestireno sulfonado para aplicações no tratamento de água produzido a partir de copos e bandejas descartadas de poliestireno" Química Nova, v. 31, pp. 8, 2008.

[19] INAGAKI, Y., KUROMYIA, M., NOGUCHI, T. et al., "Reclamation of waste polystyrene by sulfonation", Langmuir, v. 15, pp..4171-4175, Mar. 2009.

[20] SOLDI, R. A. Síntese e caracterização de catalisadores poliméricos ácidos, a partir da reciclagem química do poliestireno, e avaliação na sintese de biodiesel em fase heterogênea, Dissertation M.Sc., Federal University of Parana, Curitiba, Brazil, 2006.

[21] ORDOMSKY, V.V., SCHOUTEN, J.C., VAN DER SCHAAF, J. et al., "Foam supported sulfonated polystyrene as a new acidic material for catalytic reactions", Chemical Engineering Journal, v. 207-208, pp.218-255, Oct. 2012.

[22] KUCERA F., JANCAR, J., "Homogeneous and heterogeneous sulfonation of polymers: a review", Polymer Engineering and Science, v. 38, n. 5, pp. 783-792, Apr. 1998.

[23] KUCERA, F., Homogeneous and heterogeneous sulfonation of polystyrene, Thesis, PhD., Brno, Czec Republic, 2001.

[24] SMITHA, B., SRIDHAR, S., KHAN, A.A., "Synthesis and characterization of proton conducting polymer membranes for fuel cells", Journal of Membrane Science, v. 225, pp. 63-76, Nov. 2003.

[25] RUBingeR, C.P., CALADO, H.D., RUBINGER, R.M. et al., "Characterization of a sulfonated polycarbonate resistive humidity sensor", Sensors, v. 13, pp. 2023-2032, Feb. 2013.

[26] MARTINS, C.R., RUGGERI, G., De PAOLI, M.A., "Synthesis in pilot plant scale and physical properties of sulfonated polystyrene", Journal of the Brazilian Chemical Society, v. 14, n.5, pp.797-802, 
Sept./Oct. 2003.

[27] FERREIRA, C. F. Obtenção de superfície super-hidrofóbica a partir de nanocompósitos de PS e EPS com nanopartícupas de ZnO modificado, Dissertation, M.Sc., Centro Federal de Educação Tecnológica de Minas Gerais, Belo Horizonte, Brazil, 2016.

[28] CRISTOVAN, F.H., EIRAS, S.P., CRUZ, W.O., et al., "Preparação e caracterização óptica de filmes de poli(estireno sulfonados) dopados com neodímio", Química Nova., v. 28, pp. 964-967, Aug. 2005.

\section{ORCID}

Bruna Torres N. C. Andrade http://orcid.org/0000-0002-3756-477X

Augusto Cesar da Silva Bezerra https://orcid.org/0000-0003-1670-2376

Claudinei Calado

https://orcid.org/0000-0002-2327-1722 